\title{
Categorizing locally rare plant taxa for conservation status
}

\author{
Benjamin J. Crain · Jeffrey W. White
}

Received: 28 June 2010/ Accepted: 29 September 2010/Published online: 4 November 2010

(C) The Author(s) 2010. This article is published with open access at Springerlink.com

\begin{abstract}
Locally rare taxa are those that are rare or uncommon within a local geographical boundary while more common outside of that boundary. In addition to the rare taxa identified by global, national, and state/provincial levels, locally rare taxa are important for the preservation of species diversity and ecological processes, and therefore require effective and recognizable conservation status. Currently, there are no specific local rarity criteria in use to categorize taxa at regional jurisdictional levels. To address this need, we developed criteria for categorizing locally rare plant taxa by using the framework the Natural Heritage Network's Element Ranking System combined with attributes of the World Conservation Union's Red List Criteria. We then tested the efficacy of our classification system (called L-ranks) on the flora of Napa County using a geographic information system and available plant distribution data for the State of California. Results indicated that 89 taxa from 34 families met the area of occupancy criteria for local rarity status. Our findings demonstrated that with available geographic data, the proposed criteria for classifying locally rare plants can be usefully applied at the county level to identify significant peripheral plant populations. The proposed L-rank system was specifically designed to be compatible with existing multi-scale conservation programs and will augment the current systems in use by local organizations. By systematically classifying locally rare plants, current regulations that are applicable to locally rare taxa may be used more effectively in conservation planning and prioritizing at the county scale.
\end{abstract}

Keywords Element Ranking System - Local rarity · Napa County $\cdot$ Peripheral populations $\cdot$ Plant conservation $\cdot$ Rare plants

B. J. Crain · J. W. White $(\bowtie)$

Biodiversity Research and Education Laboratory, Department of Biological Sciences,

Humboldt State University, 1 Harpst Street, Arcata, CA 95521, USA

e-mail: jww12@humboldt.edu 


\section{Introduction}

Unlike globally rare taxa, which are rare with respect to our entire planet, locally rare taxa are those that are rare or uncommon within a local geographical boundary while more common outside of that boundary. Locally rare taxa are frequently composed of peripheral populations located at the edge of the taxon's overall range. These populations commonly have significant ecological value (Safriel et al. 1994; Lesica and Allendorf 1995; Leppig and White 2006; Thuiller et al. 2008). They often harbor unique genetic and morphological lineages that provide the opportunity for divergence along novel evolutionary paths through the processes of natural selection (Safriel et al. 1994; Lesica and Allendorf 1995; Gaston 2003). Maintenance of genetic variation by locally rare plants increases the probability of overall species survival (Lesica and Allendorf 1992; Lesica and Allendorf 1995) and locales with peripheral populations often act as refugia during catastrophic range contractions (Safriel et al. 1994; Channell and Lomolino 2000). Peripheral plant populations also provide the flexibility required for responding to stochastic environmental events such as global climate change (Safriel et al. 1994; Smith et al. 2001; Leppig and White 2006; Thuiller et al. 2008). Furthermore, many plants, regardless of their rarity status, have intrinsic cultural, economic, and aesthetic value (Ehrlich and Ehrlich 1992; Daily et al. 2000; Gaston 2003). Unfortunately, locally rare taxa are susceptible to the same threats that affect all rare and endangered ecological communities.

Although there is current legislation in the United States designed to protect rare plants within large jurisdictions (e.g. CESA 1970; ESA 1973; CEQA 2005), most conservation efforts and development decisions happen at local and regional scales (Reid 1998; Brooks et al. 2006; Leppig and White 2006). In addition to the rare taxa identified by global, national, and state or provincial agencies, locally rare taxa are important for the preservation of species diversity, and therefore require effective and recognizable conservation status.

Pärtel et al. (2005) conclude that in the case of vascular plants, an analysis of multiple conservation characteristics, including restricted global and local distributions, would provide a powerful and objective tool for conservation planning. They further highlight that "biogeographic reasons" may play an important role in determining local abundance of a species, and that the area of a species distribution is the most common characteristic associated with conservation need. Furthermore, White (2004) demonstrated that area of occupancy, when used with an optimal methodology, significantly reduces experimental error for the estimation of range size, especially for rare taxa. Thus, analysis of area of occupancy criteria is important for plant conservation efforts.

Although Magney (2004) directly applied the Natural Heritage Network Element Ranking System's (NatureServe 2006) criteria for the sub-national assessment scale to a county jurisdiction (Ventura, California), there are no specific local rarity ranks or criteria presently in use to systematically categorize taxa at the county level. Furthermore, when the absence of a standardized summary system is coupled with a frequent lack of accurate distribution data, locally rare taxa are not well integrated into conservation planning efforts. Regrettably due to such vagueness, repeatable studies are difficult and germane regulations are often not effectively applied to locally rare taxa (Leppig and White 2006). Nevertheless, several programs have been developed using various methods in attempts to identify and protect locally rare plants (see CNPS 2010).

The purpose of this research was to develop and outline a set of criteria for systematically categorizing and assigning conservation ranks to locally rare taxa. The aim was to 
address the current gap in the available methods for classifying biodiversity at local assessment scales (e.g., counties) in order to catalog locally rare organisms and give them conservation status. After briefly summarizing and analyzing current conservation status criteria, we introduce a proposed set of criteria that are applicable to locally rare taxa and compatible with currently established conservation systems used for larger jurisdictions. We assessed the efficacy of the new criteria by applying them to the flora of Napa County, CA. Our goal is to create a standardized protocol for identifying and categorizing locally rare plant taxa at the local or regional jurisdictional levels.

\section{Background}

Two leading international conservation organizations, The Natural Heritage Network (NatureServe) and the World Conservation Union (IUCN), have developed and implemented criteria for categorizing rare species by using combinations of quantitative and qualitative measures. Criteria are based on geographic, demographic, and ecological characteristics such as range sizes (using various methods), number of occurrences, population sizes, threat levels, and/or extinction probabilities (see IUCN 2001; NatureServe 2006 for complete descriptions). While these systems are not designed to classify locally rare taxa, they serve as excellent models for the development of a new system designed specifically to accomplish this task.

NatureServe employs a series of criteria to classify taxa into five "Element Ranks" based on their level of rarity, threat level, and population/range size trends, and uses three prefix letters (G, N, and S) to designate the geographic assessment level (Global, National, and Sub-national) of the assigned rank (NatureServe 2006; Master et al. 2009). Benefits of NatureServe's methods include specific numerical criteria for identifying rarity by range size, population size, and number of element occurrences, as well as their applicability to multiple geographic scales and taxonomic levels. Recent updates to this system assign higher weightings to threats and trends, and thus create ranks that are closer to measuring actual vulnerability (Master et al. 2009). Overall clarity and descriptiveness of category nomenclature is also a positive attribute of the NatureServe system.

The IUCN uses its own system to categorize rare taxa on its RED List which includes specific criteria based on geographic range size, population decline, overall population size, and probability of extinction (IUCN 2001). The IUCN system categorizes species into three threat categories: Critically Endangered, Endangered, and Vulnerable. It should be noted that many of the IUCN's criteria for individual categories, including those for area of occupancy and population numbers, do not operate alone. For example, a taxon may need to meet specific area of occupancy criteria as well as specific thresholds for two other criteria, such as extreme fragmentation and population decline, to be included in a given threat category. Additionally, many of the criteria have optional temporal components to them, such as probability of extinction within a given time frame.

In both the NatureServe and IUCN systems, their criteria for area of occupancy provide the most concrete thresholds that are readily measurable at any given time and are compatible with current data sets and tools for geographic analysis. Area of occupancy criteria for local scales has become the preferred method in which geographical data is quantified, summarized, and used for comparative analyses (Williams et al. 1996; White 1999; Draper et al. 2003). Therefore, we focus specifically on these geographic measures to develop our proposed local rarity ranking system. 


\section{Classifying local rarity}

Based on our review of NatureServe's and the IUCN's systems, we establish a new local assessment level (L-rank) for categorizing locally rare taxa within local jurisdictions and geographic regions. Under this proposed system, a taxon will be considered locally rare if it meets minimum area of occupancy levels using grids composed of $1 \mathrm{~km} \times 1 \mathrm{~km}$ $\left(1 \mathrm{~km}^{2}\right)$ cells. Although grids composed of $2 \mathrm{~km} \times 2 \mathrm{~km}$ cells are commonly used in factoring the $\mathrm{G}, \mathrm{N}$, and $\mathrm{S}$ ranks, data were available at a $1 \mathrm{~km}^{2}$ scale. Cells of this size create a more accurate picture and thereby alleviate some of the problems associated with models based on larger cell sizes (Thuiller et al. 2008). At the same time, $1 \mathrm{~km}^{2}$ cells are compatible with other commonly used metric grids (e.g., 1 ha or $100 \mathrm{~km}^{2}$ cells), thus simplifying conversion of data to other scales. Moreover, unlike global, national, or subnational assessments, it is less prohibitive to collect local data at the $1 \mathrm{~km}^{2}$ scale within a reasonable amount of time and level of effort. Accordingly, the L-rank category is an incorporation and modification of aspects of the NatureServe and IUCN systems and is specifically designed to be used in conjunction with NatureServe's original geographic assessment scales.

To identify and classify locally rare taxa through geographic analysis, we outline specific area of occupancy criteria to designate different levels of rarity at the local scale. While we lend our support to the IUCN's explicit area of occupancy criteria for larger scales, the same numbers cannot be logically applied to local assessment levels due to the fact that many local jurisdictions are relatively small and have an overall area of $<2,000 \mathrm{~km}^{2}$, the maximum range to be considered for conservation status (IUCN 2001). If the IUCN's area of occupancy criteria were applied to these small jurisdictions, taxa distributed throughout the entire county would still meet the minimum criteria for conservation status at the local assessment level. Therefore, we created new area of occupancy criteria specifically for the local assessment level (Table 1). Numerical criteria were chosen qualitatively based upon analysis of criteria used by other systems, available information on average county sizes in the United States, and reviews of research showing the effects of range size on susceptibility to environmental and biological stressors. The "Critically Imperiled" range size criteria of $10 \mathrm{~km}^{2}$ used in our system is based directly on the IUCN criteria for "Critically Endangered" as it is a good measure of extreme rarity and vulnerability. The criteria in our system for "Imperiled" and "Vulnerable to Threat or Extinction" increase exponentially from the criteria for "Critically Imperiled" in a manner

Table 1 Criteria for proposed L-rank system based on area of occupancy using $\mathrm{km}^{2}$ raster grid cells

\begin{tabular}{ll}
\hline L-rank categories & Criteria \\
\hline $\mathrm{X}=$ Presumed extinct & $\begin{array}{c}\text { Not located despite extensive searches and virtually } \\
\text { no likelihood of rediscovery }\end{array}$ \\
$\mathrm{H}=$ Possibly extinct & $\begin{array}{c}\text { Missing; known from only historical occurrences but still some } \\
\text { hope of rediscovery }\end{array}$ \\
$1=$ Critically imperiled & Area $<10 \mathrm{~km}^{2}$ (or fewer then ten $1 \mathrm{~km}^{2}$ cells) \\
$2=$ Imperiled & Area $<50 \mathrm{~km}^{2}$ (or fewer then fifty $1 \mathrm{~km}^{2}$ cells) \\
$3=$ Vulnerable to threat or extinction & Area $<250 \mathrm{~km}^{2}$ (or fewer then two hundred fifty $1 \mathrm{~km}^{2}$ cells) \\
$4=$ Apparently secure & Uncommon but not rare, some cause for long-term concern \\
& due to declines or other factors \\
$5=$ Demonstrably widespread, & Common; widespread and abundant \\
abundant, and secure &
\end{tabular}


similar to the IUCN system but were downscaled to a more appropriate size for county level assessments.

In sum, the unique features included in our proposed system for categorizing locally rare taxa are (1) scaling of the geographic assessment level to correspond with local rarity, the L-rank, and (2) inclusion of defined area of occupancy criteria for L-ranks 1, 2, and 3 (Table 1). Thus, a taxon that meets "Critically Imperiled" criteria at all geographical assessment levels could now be labeled G1N1S1L1, representing critical imperilment at global, national, sub-national, and local levels. Likewise, a taxon that is common at the global, national, and sub-national levels, but rare in a given county, could be labeled G5N5S5L1 and thus receive conservation status within the local jurisdiction. These examples demonstrate how the proposed L-rank system is intended to be viewed as an extension of the NatureServe and IUCN systems that enables local jurisdictions to identify and manage locally rare species.

\section{A case study of local rarity}

Using the flora of Napa County, California as a case study system, we tested the efficacy of the proposed L-rank criteria to classify and catalog the locally rare plant populations of the region. We chose Napa County for our case study due to its high level of plant diversity (Stebbins and Major 1965; Parisi 2003; Crain and White unpublished data) and due to the large number of plant taxa who reach the edge of their range in Napa (Thorne et al. 2004). Furthermore, Napa is rich with geographical and floristic data (Stoms et al. 2005).

Although numerous botanical surveys have been conducted in Napa County (Major unpublished data, Stebbins and Major 1965; Jepson Flora Project 2005; CCH 2010) resulting in large databases of plant collection records, no checklist or flora has been published specifically for the region. Therefore, we developed a comprehensive plant checklist for Napa County (Crain and White unpublished data), making both this and future research possible. We compiled all vouchered records for native plant taxa listed on the Jepson Herbaria Online Inventory for California Floristics SMASCH database and the Consortium of California Herbaria (Jepson Flora Project 2005; CCH 2010), Calflora (2000), the California Native Plant Society's Inventory of Rare and Endangered Plants (2005), with personal observations from 2005 to 2007. These sources were chosen due to their representation of significant local and regional herbaria. Although there are likely to be some data gaps in these collections as a result of variable sampling efforts or techniques, these data sources remain highly significant as they represent the most comprehensive collection of plant diversity for the area that is based on decades of primary research. Each available record was screened for nomenclatural errors and updates using Fred Hrusa's Crosswalk (2005). The resulting checklist (available upon request) included 1,418 native plant taxa for Napa County.

For our initial geographical analysis, we used the CaprICE Plant Species Distribution Map Browser (available at http://cain.ice.ucdavis.edu/cgi-bin/mapserv?map=../html/cain/ plants_animals/plants/caprice/capricemap.map\&mode=browse\&layer=county) which allows online access to a plant distribution map series based on the CalJep Geodatabase (Viers et al. 2006). This database is developed from distributional information available from the Jepson Flora Project and the Calflora database. The CalJep Geodatabase maps show statewide plant distributions in California using $1 \mathrm{~km} \times 1 \mathrm{~km}$ grid cells (Viers et al. 2006). We used these maps to visually identify several hundred native plant taxa in Napa County as candidates for local rarity status (LH, L1, L2, and L3) based on our proposed 
area of occupancy criteria (Table 1). All native plant taxa listed for Napa County that did not currently meet the criteria for one of the threat categories at the global, national, or state assessment levels (CNDDB 2007), and with distributions estimated to be less than $50 \%$ of Napa's overall area of $\approx 2,052 \mathrm{~km}^{2}$ (United States Census Bureau 2000) were considered candidates for local conservation status. For all candidate taxa, Allan Hollander of the Information Center for the Environment and the Department of Environmental Science and Policy at the University of California-Davis, provided geographic data layers from the CalJep spatial distribution database. Each layer showed the statewide distribution of an individual candidate taxon based on $1 \mathrm{~km} \times 1 \mathrm{~km}$ raster grid cells. Layers were generated by intersecting distribution data (elevation, presence in subecoregions, and subcounty distributions) from the Jepson Manual and its online counterpart, the Jepson Online Interchange, as well as from Calflora circa 2000 (Viers et al. 2006). In these databases distribution information was generated from collection records and expert observations, however, the Jepson Online Interchange is more restricted to collection records and was therefore considered the foremost authority when discrepancies occurred (Viers et al. 2006).

We imported all statewide layers into Arc GIS 9.1 (ESRI 2005) for more detailed analysis. Each data layer was reclassified with Spatial Analyst to create new layers with a binary code indicating presence or absence of the taxon in each $1 \mathrm{~km}^{2}$ raster cell in California. A mask layer for Napa County was created by reclassifying our layer for the State of California to create a new layer with a binary code distinguishing Napa from the rest of the state. We multiplied the statewide distribution layers for individual taxa with the Napa County mask layer to create new layers isolating plant distributions within Napa County (cells with a product of one). We queried the attribute tables in the resulting layers and then classified those taxa with distributions meeting the minimum area of occupancy criteria for local rarity $\left(<250 \mathrm{~km}^{2}\right)$ into one of the three threat categories (L1, L2, L3) or the LH category.

\section{Results}

Our results indicated that 89 taxa from 34 families met the area of occupancy criteria for local rarity ranks $1,2,3$, and $\mathrm{H}$ in Napa County, CA (Table 2). Figure 1 shows examples of the distributions of three L-ranked plants (categories 1, 2, and 3) based on analysis using $1 \mathrm{~km}^{2}$ grid cells. Although each of these taxa exhibits a relatively large distribution in California, they are all rare to some degree in Napa County. A post-hoc analysis of the distributions of the locally rare taxa identified in this study revealed that these plants are distributed in an average of 20 counties in California. This indicates that they are relatively widespread in the state and would fail to meet criteria for conservation status at state or global levels but could be given status at the local level via the L-rank system.

The number of locally rare plants identified using the proposed criteria equated to a total of $6.3 \%$ of Napa's 1,418 native plant taxa (Crain \& White unpublished data). Of these L-ranked plants, nine taxa from eight families met the criteria for L-rank 1, equating to $0.63 \%$ of Napa's native flora. Another 13 taxa from nine families met the criteria for L-rank 2, equating to $0.91 \%$ of Napa's native flora. Furthermore, 34 taxa from 21 families met the criteria for L-rank 3, equating to $2.39 \%$ of Napa's native flora. The remaining 33 taxa, representing 19 families and $2.32 \%$ of Napa's native flora, met the criteria for the L-rank H according to available distribution data. Although the geographic data published by Viers et al. (2006) includes no evidence that these 33 taxa are present in Napa County, it is 
Table 2 Native locally rare plant taxa distributed in Napa County

\begin{tabular}{|c|c|c|}
\hline L-rank & Taxon & Family \\
\hline L1 & $\begin{array}{l}\text { Lomatium dasycarpum (Torr. \& A. Gray) J.M. Coult. \& Rose } \\
\text { ssp. tomentosum (Benth.) Theob. }\end{array}$ & Apiaceae \\
\hline L1 & Silene lemmonii S. Watson & Caryophyllaceae \\
\hline L1 & Carex brainerdii Mack. & Cyperaceae \\
\hline L1 & Chimaphila menziesii (D. Don) Spreng. & Ericaceae \\
\hline L1 & Phacelia mutabilis Greene & Hydrophyllaceae \\
\hline L1 & Calochortus venustus Benth. & Liliaceae \\
\hline L1 & Bromus grandis (Shear) Hitchc. & Poaceae \\
\hline L1 & Elymus glaucus Buckley ssp. jepsonii (Burtt Davy) Gould & Poaceae \\
\hline L1 & Ceanothus prostratus Benth. & Rhamnaceae \\
\hline L2 & Eryngium armatum (S. Watson) J.M. Coult. \& Rose & Apiaceae \\
\hline $\mathrm{L} 2$ & Gnaphalium bicolor Bioletti & Asteraceae \\
\hline L2 & $\begin{array}{l}\text { Gnaphalium canescens DC. ssp. microcephalum (Nutt.) Stebb. } \\
\text { \& D.J. Keil }\end{array}$ & Asteraceae \\
\hline L2 & $\begin{array}{l}\text { Heterotheca sessiliflora (Nutt.) Shinn. ssp. bolanderi (A. Gray) } \\
\text { Semple }\end{array}$ & Asteraceae \\
\hline L2 & Barbarea orthoceras Ledeb. & Brassicaceae \\
\hline L2 & Dudleya caespitosa (Haw.) Britton \& Rose & Crassulaceae \\
\hline L2 & Juncus lesueurii Bol. & Juncaceae \\
\hline $\mathrm{L} 2$ & Juncus occidentalis (Coville) Wiegand & Juncaceae \\
\hline L2 & Juncus phaeocephalus Engelm. var. phaeocephalus & Juncaceae \\
\hline L2 & Forestiera pubescens Nutt. & Oleaceae \\
\hline L2 & Limonium californicum (Boiss.) A. Heller & Plumbaginaceae \\
\hline $\mathrm{L} 2$ & Ceanothus dentatus Torr. \& A. Gray & Rhamnaceae \\
\hline $\mathrm{L} 2$ & Penstemon newberryi A. Gray var. sonomensis & Scrophulariaceae \\
\hline L3 & Angelica tomentosa $\mathrm{S}$. Watson & Apiaceae \\
\hline L3 & Bowlesia incana Ruiz \& Pav. & Apiaceae \\
\hline L3 & Lomatium vaginatum (M.E. Jones) J. Coulter \& Rose & Apiaceae \\
\hline L3 & Erigeron reductus (Cronq.) G.L. Nesom var. ruductus & Asteraceae \\
\hline L3 & $\begin{array}{l}\text { Erigeron reductus (Cronq.) G.L. Nesom var. angustatus } \\
\text { (A. Gray) G.L. Nesom }\end{array}$ & Asteraceae \\
\hline L3 & Grindelia stricta DC. var. angustifolia (A. Gray) M.A. Lane & Asteraceae \\
\hline L3 & Jaumea carnosa (Less.) A. Gray & Asteraceae \\
\hline L3 & Plagiobothrys canescens Benth. & Boraginaceae \\
\hline L3 & Idahoa scapigera (Hook.) A. Nelson \& J.F. Macbr. & Brassicaceae \\
\hline L3 & Streptanthus brachiatus F.W. Hoffmann ssp. brachiatus & Brassicaceae \\
\hline L3 & Paxistima myrsinites (Pursh) Raf. & Celastraceae \\
\hline L3 & Dichondra donelliana Tharp \& M.C. Johnst. & Convolvulaceae \\
\hline L3 & Bergia texana (Hook.) Seub. & Elatinaceae \\
\hline L3 & Lotus pinnatus Hook. & Fabaceae \\
\hline L3 & Garrya flavescens S. Watson & Garryaceae \\
\hline L3 & Geranium bicknellii Britton & Geraniaceae \\
\hline L3 & Hydrophyllum occidentale (S. Watson) A. Gray & Hydrophyllaceae \\
\hline L3 & Triglochin maritima L. & Juncaginaceae \\
\hline
\end{tabular}


Table 2 continued

\begin{tabular}{|c|c|c|}
\hline L-rank & Taxon & Family \\
\hline L3 & Monardella sheltonii Torr. & Lamiaceae \\
\hline L3 & Allium lacunosum S. Watson var. Lacunosum & Liliaceae \\
\hline L3 & Epilobium halleanum Hausskn. & Onagraceae \\
\hline L3 & Elymus elymoides (Raf.) Swezey & Poaceae \\
\hline L3 & Leptochloa fascicularis (Lam.) A. Gray & Poaceae \\
\hline L3 & Spartina foliosa Trin. & Poaceae \\
\hline L3 & Collomia grandiflora Lindl. & Polemoniaceae \\
\hline L3 & $\begin{array}{l}\text { Navarretia divaricata (A. Gray) Greene ssp. vividior } \\
\text { (Jeps. \& V.L. Bailey) H. Mason }\end{array}$ & Polemoniaceae \\
\hline L3 & Cheilanthes covillei Maxon & Pteridaceae \\
\hline L3 & Ceanothus pumilus Greene & Rhamnaceae \\
\hline L3 & Acaena pinnatifida Ruiz \& Pav.var. californica (Bitter) Jeps. & Rosaceae \\
\hline L3 & Potentilla anserina L. ssp. Anserina & Rosaceae \\
\hline L3 & Potentilla anserina L. ssp. pacifica (Howell) Rousi & Rosaceae \\
\hline L3 & Collinsia tinctoria Benth. & Scrophulariaceae \\
\hline L3 & Cordylanthus mollis A. Gray ssp. mollis & Scrophulariaceae \\
\hline L3 & Cordylanthus pringlei A. Gray & Scrophulariaceae \\
\hline $\mathrm{LH}$ & Eryngium vaseyi J.M. Coult. \& Rose & Apiaceae \\
\hline LH & $\begin{array}{l}\text { Lomatium caruifolium (Hook. \& Arn.) J.M. Coult. \& Rose } \\
\text { var. denticulatum Jeps. }\end{array}$ & Apiaceae \\
\hline LH & $\begin{array}{l}\text { Lomatium dissectum (Torr. \& A. Gray) Mathias \& Constance } \\
\text { var. dissectum }\end{array}$ & Apiaceae \\
\hline $\mathrm{LH}$ & Lemna trisulca $\mathrm{L}$. & Araceae \\
\hline $\mathrm{LH}$ & $\begin{array}{l}\text { Balsamorhiza macrolepis W.M. Sharp var. platylepis } \\
\text { (W.M. Sharp) Ferris }\end{array}$ & Asteraceae \\
\hline $\mathrm{LH}$ & Erigeron foliosus Nutt. var. Foliosus & Asteraceae \\
\hline $\mathrm{LH}$ & Gutierrezia sarothrae (Pursh) Britton \& Rusby & Asteraceae \\
\hline $\mathrm{LH}$ & $\begin{array}{l}\text { Pyrrocoma racemosa (Nutt.) Torr. \& A. Gray var. paniculata } \\
\text { (Nutt.) Kartesz \& Gandhi }\end{array}$ & Asteraceae \\
\hline LH & Senecio integerrimus Nutt. var. exaltatus (Nutt.) Cronq. & Asteraceae \\
\hline $\mathrm{LH}$ & Stephanomeria virgata Benth. ssp. virgata & Asteraceae \\
\hline $\mathrm{LH}$ & Wyethia mollis A. Gray & Asteraceae \\
\hline $\mathrm{LH}$ & Plagiobothrys cusickii (Greene) I.M. Johnst. & Boraginaceae \\
\hline LH & Arabis sparsiflora Torr. \& A. Gray var. arcuata (Nutt) Rollins & Brassicaceae \\
\hline $\mathrm{LH}$ & Calystegia malacophylla (Greene) Munz ssp. malacophylla & Convolvulaceae \\
\hline LH & Arctostaphylos viscida Parry ssp. viscida & Ericaceae \\
\hline $\mathrm{LH}$ & Lupinus albicaulis Hook. & Fabaceae \\
\hline $\mathrm{LH}$ & Isoetes orcuttii A.A. Eaton & Isoetaceae \\
\hline $\mathrm{LH}$ & Juncus orthophyllus Coville & Juncaceae \\
\hline $\mathrm{LH}$ & Juncus phaeocephalus Engelm. var. paniculatus Engelm. & Juncaceae \\
\hline $\mathrm{LH}$ & Triteleia ixioides (S. Watson) Greene ssp. scabra (Greene) L. Lenz & Liliaceae \\
\hline $\mathrm{LH}$ & Zigadenus paniculatus (Nutt.) S. Watson & Liliaceae \\
\hline LH & Camissonia luciae P.H. Raven & Onagraceae \\
\hline $\mathrm{LH}$ & Clarkia bottae (Spach) F.H. Lewis \& M.R. Lewis & Onagraceae \\
\hline LH & Gaura coccinea Pursh & Onagraceae \\
\hline
\end{tabular}


Table 2 continued

\begin{tabular}{lll}
\hline L-rank & Taxon & Family \\
\hline LH & Mimulus alsinoides Benth. & Phrymaceae \\
LH & Achnatherum coronatum (Thurb.) Barkworth & Poaceae \\
LH & $\begin{array}{l}\text { Allophyllum gilioides } \text { (Benth.) A.D. Grant \& V.E. Grant ssp. } \\
\text { violaceum (A. Heller) A.G. Day }\end{array}$ & Polemoniaceae \\
& Calyptridium roseum S. Watson & Portulacaceae \\
LH & Galium andrewsii A. Gray ssp. intermedium Dempster \& Stebb. & Rubiaceae \\
LH & Galium angustifolium Nutt. ssp. angustifolium & Rubiaceae \\
LH & Salix melanopsis Nutt. & Salicaceae \\
LH & Castilleja lacera (Benth.) Chuang \& Heckard & Scrophulariaceae \\
LH & Veronica serpyllifolia L. ssp. humifusa (Dicks.) Syme & Scrophulariaceae \\
\hline
\end{tabular}

L-ranks are based strictly on area of occupancy criteria outlined in Table 1

possible that the taxa are present and actually meet criteria for L-rank 1, 2, or 3 as each of them are documented in Napa County through collection records or observations by a botanical expert. However, the distribution data for these taxa stems from information included on Calflora and the Jepson Manual/Online Interchange (Viers et al. 2006; Calflora 2000; Jepson Flora Project 2005; CCH 2010) and does not entirely correspond with available collection data. Additionally, Calflora includes records from multiple sources that are of variable degrees of reliability (Calflora 2000). To be conservative, listings from Calflora that were not represented by a collection record, documented by an expert on site, or corroborated through another source (e.g., Jepson Flora Project 2005; CNPS 2005; or $\mathrm{CCH} 2010$ ) were not included in this analysis. Nevertheless, few plant checklists are $100 \%$ accurate and when multiple datasets are combined or compared there is often conflicting information due to variation in collecting efforts, taxonomic updates, synonymy, and timing. Therefore, due to these minor inconsistencies between the collection records and the available distribution data, the L-rank "H?" was assigned to these taxa, thus maintaining the integrity of the methodology.

\section{Discussion}

Although Magney (2004) argues that NatureServe's Element Ranking System can be applied to county scales in some instances, in most cases, all criteria used by NatureServe cannot be logically and effectively applied to local jurisdictions due to size constraints. In short, because of variation in jurisdictional areas, NatureServe's exact criteria should not be used as the entire basis for setting local rarity criteria. The Element Ranking System is a valuable system at larger scales however, and it provided the framework for classifying local rarity.

The IUCN Red List was also a valuable model for developing the L-rank system but again, their criteria cannot be applied directly to local jurisdictions. IUCN Red List criteria, such as those for population decline or probability of extinction, can be valuable tools for assigning conservation priority to threatened taxa. Nevertheless, these are measures that are dynamic over time and distinguishing taxa that meet these criteria can require longterm analysis (10 years or more) in situations where available time and data are quite limited. 


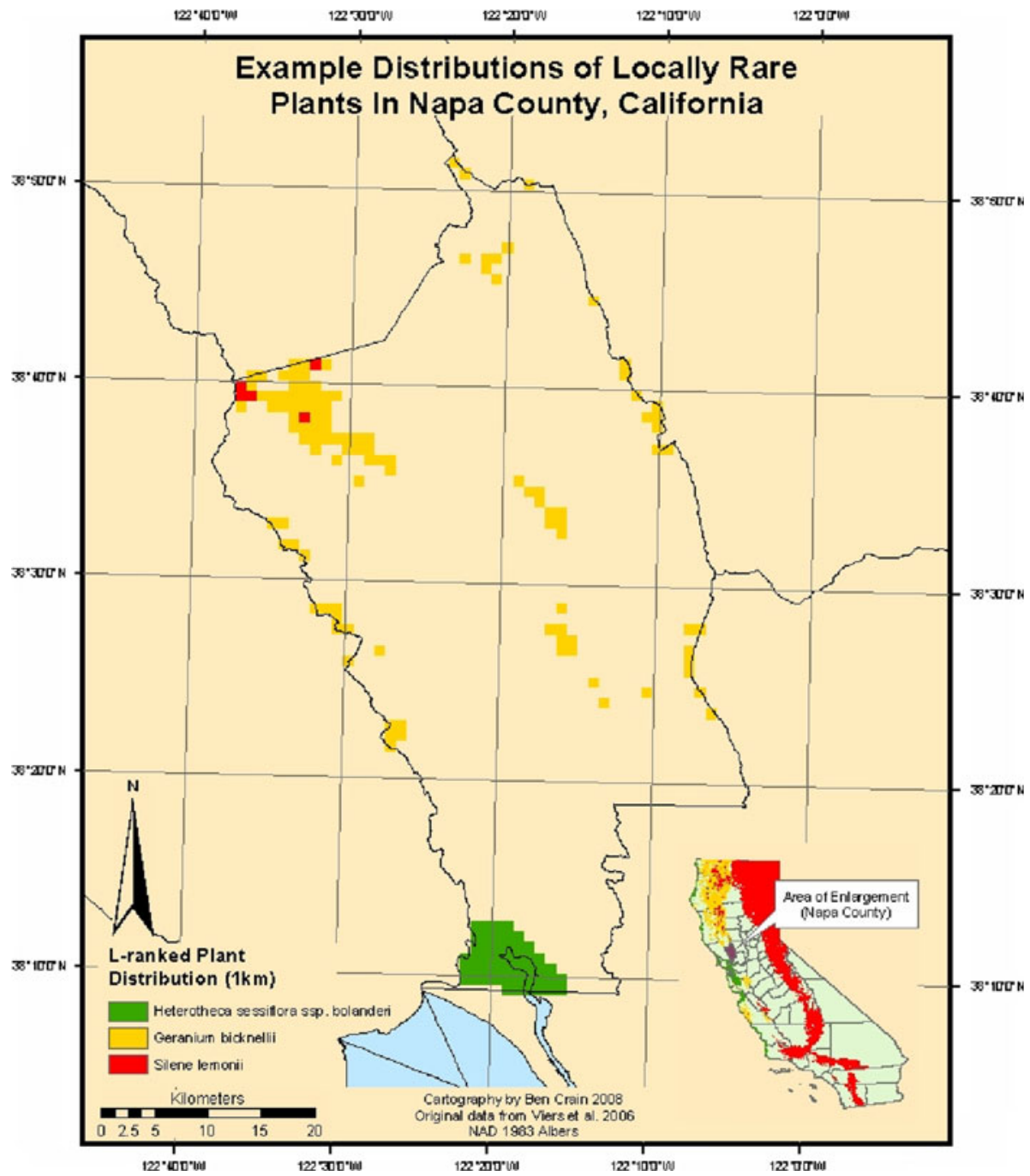

Fig. 1 Examples of the distributions of three L-ranked plants (category L1-Silene lemonii, L2Heterotheca sessiflora ssp. bolanderi, and L3-Geranium. bicknellii) in Napa County based on occupancy of $1 \mathrm{~km}^{2}$ grid cells

The inclusion of a local rarity rank into a recognized system is meant to enhance existing methods used by local governments and organizations by providing them with a standardized system for local level analysis. The proposed L-rank system is specifically designed to be compatible with broad scale conservation programs, specifically NatureServe's Element Ranking System and the IUCN Red List. Therefore, it is important to realize that using the proposed system will not significantly affect overall assessment outcomes at the sub-national, national, or global levels. Rather, the proposed local rarity criteria will provide a useful tool for comparative analysis at the local level and significantly augment the current systems in use. 
Through the analysis of the distributions of globally common plants in Napa County, we identified several locally rare plant taxa using the proposed L-rank criteria. The results presented here indicate that with available geographical data, our criteria for classifying locally rare plants can be usefully applied at the county level to identify significant peripheral or 'edge of range' plant populations. Much as the S-rank can be applied to state or provincial boundaries, we encourage the use of the L-rank system in other local jurisdictional areas that are similar in size to a typical county, e.g., national parks, watersheds, or municipalities, when applicable. Individual jurisdictions are geographically unique in size and shape however, and these factors should be considered when applying this system to any area.

Many biologically significant locally rare plant populations highlighted in this analysis are not currently considered for conservation status by global and national conservation policies. These unique organisms deserve conservation status and county agencies should manage them accordingly. Additionally, similar research needs to be conducted in other local jurisdictions to enhance our understanding of the ecological factors affecting the distributions of locally rare plant taxa.

Without an explicit set of criteria for identifying and classifying locally rare taxa, they cannot be effectively protected. The proposed L-rank system provides an effective and systematic tool to address this issue. We suggest that the ecological significance and conservation status of the locally rare plants identified in this study be further evaluated. Use of the L-rank system at local levels will allow researchers to fill the data gap concerning locally rare peripheral plant populations and help to highlight their significance in regards to the global environment.

Acknowledgments We thank the members of the Biodiversity Research and Education Laboratory at Humboldt State University for their assistance with this manuscript. We also give special thanks to $\mathrm{S}$. Steinberg at the Humboldt State University Institute for Spatial Analysis for his invaluable assistance with the GIS portions of this research and A. Hollander at the Information Center for the Environment at University of California-Davis for providing us with distribution data. We greatly appreciate the insightful and extremely useful comments provided by two anonymous reviewers. Finally, and most importantly, we thank our families and our friends, A. Allard, G. Leppig and S. Calderón, for their support during this research.

Open Access This article is distributed under the terms of the Creative Commons Attribution Noncommercial License which permits any noncommercial use, distribution, and reproduction in any medium, provided the original author(s) and source are credited.

\section{References}

Brooks TM, Mittermeier RA, da Fonseca GAB, Gerlach J, Hoffman M, Lamoreaux JF, Mittermeier CG, Pilgrim JD, Rodrigues ASL (2006) Global biodiversity conservation priorities. Science 313:58-61

Calflora (2000) Information on California Plants for Education, Research, and Conservation. Berkeley, CA. http://www.Calflora.org/. Cited June 2005

California Department of Fish and Game, Natural Diversity Database (CNDDB) (2007) Special Vascular Plants, Bryophytes, and Lichens List. Biogeographic Data Branch- Department of Fish and Game, Sacramento, CA

California Endangered Species Act (CESA) (1970) Department of Fish and Game Codes 2050-2116

California Environmental Quality Act, The (CEQA) (2005) Public resources code 21000-21177 and the CEQA guidelines (California Code of Regulations, Title 14, Division 6, Chapter 3, Sections 1500015387)

California Native Plant Society (CNPS) (2005) CNPS Inventory of Rare and Endangered Plants. Sacramento, CA. http://cnps.web.aplus.net/cgi-bin/inv/inventory.cgi. Cited June 2005

California Native Plant Society (CNPS) (2010) CNPS Rare Plant Program. Sacramento, CA. http://www.cnps.org/cnps/rareplants/locally_rare.php. Cited August 2010 
Channell R, Lomolino MV (2000) Dynamic biogeography and conservation of endangered species. Nature 403:84-86

Consortium of California Herbaria (CCH) (2010) http://ucjeps.berkeley.edu/consortium/. Cited August 2010

Daily GC, Soderqvist T, Aniyar S, Arrow K, Dasgupta P, Ehrlich PR, Folke C, Jansson A, Jansson B, Kautsky N, Levin S, Lubchenco J, Maler K, Simpson D, Starrett D, Tilman D, Walker B (2000) The value of nature and the nature of value. Science 289:395-397

Draper D, Rossello-Graell A, Garcia C, Gomes CT, Sergio C (2003) Application of GIS in plant conservation programs in Portugal. Biol Conserv 113:337-349

Ehrlich PR, Ehrlich AH (1992) The value of biodiversity. Ambio 21:219-226

Endangered Species Act, The (ESA) (1973) The United States Constitution, Sections 1531-1543

Environmental Systems Research Institute, Inc. (ESRI) (2005) ArcGIS 9.1. Redlands, CA

Gaston K (2003) The structure and dynamics of geographic ranges. Oxford University Press, New York, NY

Hrusa F (2005) Fred Hrusa's CROSSWALK. Jepson Herbarium. Berkeley, CA. http://ucjeps.berkeley. edu/xw.html. Cited June 2005-2007

Jepson Flora Project (2005) The Jepson Herbaria Online Inventory for California Floristics SMASCH Database, Jepson Herbarium. Berkeley, CA. http://ucjeps.berkeley.edu/interchange.html. Cited June 2005-2007

Leppig G, White J (2006) Conservation of peripheral plant populations in California. Madroño 53:264-274

Lesica P, Allendorf FW (1992) Are small populations of plants worth saving? Conserv Biol 6:135-139

Lesica P, Allendorf FW (1995) When are peripheral populations valuable for conservation? Conserv Biol 9:753-760

Magney D (2004) Acceptability of Using the Natural Heritage Program's Species Ranking System for Determining Ventura County Locally Rare Plants. http://www.cnpsci.org/PlantInfo/01RarePlants.htm. Cited August 2010

Master L, Faber-Langendoen D, Bittman R, Hammerson G, Heidel B, Nichols J, Ramsay L, Tomaino A (2009) Natureserve conservation status assessments: factors for assessing extinction risk. NatureServe, Arlington, VA

NatureServe (2006) NatureServe Explorer: An online encyclopedia of life [web application]. Version 6.1. NatureServe, Arlington, VA. http://www.natureserve.org/explorer/ranking.htm. Cited October 2005-2008

Parisi M (ed) (2003) Atlas of the biodiversity of California. California Department of Fish and Game, Sacramento, CA

Pärtel M, Kalamees R, Reier Ü, Tuvi E, Roosaluste E, Vellak A, Zobel M (2005) Grouping and prioritization of vascular plant species for conservation: natural rarity and management need. Biol Conserv $123: 271-278$

Reid W (1998) Biodiversity hotspots. Trends Ecol Evol 13:275-280

Safriel UN, Volis S, Kark S (1994) Core and peripheral populations and global climate change. Israel J Plant Sci 42:331-345

Smith TB, Kark S, Schneider CJ, Wayne RK, Moritz C (2001) Biodiversity hotspots and beyond: the need for preserving environmental transitions. Trends Ecol Evol 16:431

Stebbins GL, Major J (1965) Endemism and speciation in the California flora. Ecol Monogr 35:1-35

Stoms DM, Comer PJ, Crist PJ, Grossman DH (2005) Choosing surrogates for biodiversity conservation in complex planning environments. J Conserv Plan 1:44-63

Thorne JH, Kennedy JA, Quinn JF, McCoy M, Keeler-Wolf T, Menke J (2004) A vegetation map of Napa County using the manual of California vegetation classification and its comparison to other digital vegetation maps. Madroño 51:343-363

Thuiller W, Albert C, Araújo M, Berry PM, Cabeza M, Guisan A, Hickler T, Midgley GF, Patterson J, Schurr FM, Sykes MT, Zimmerman N (2008) Predicting global change impacts on plant species' distributions: future challenges. Perspect Plant Ecol Evol Syst 9:137-152

United States Census Bureau (2000) State and County Quick Facts. http://www.census.gov. Cited July 2007

Viers JH, Thorne JH, Quinn JF (2006) CalJep: A spatial distribution database of Calflora and Jepson plant species. San Francisco Estuary \& Watershed Science 4. Available via http://repositories.cdlib.org/cgi/ viewcontent.cgi? article $=1018 \&$ context=jmie/sfews

White J (1999) Rarity and the phylogeography of the large-flowered Piptolobi of Astragalus L. (Fabaceae). Doctor of Philosophy dissertation, Department of Botany and Plant Pathology, Michigan State University, East Lansing, MI

White J (2004) Range size, error rates, and the geometry of rare species distributions. Proceedings of the 2002 rare plant symposium: the ecology and management of rare plants of northwestern California. California Native Plant Society, Sacramento, CA 
Williams P, Gibbons D, Margules C, Rebelo A, Humphries C, Pressey R (1996) A comparison of richness hotspots, rarity hotspots, and complementary areas for conserving diversity of British birds. Conserv Biol 10:155-174

World Conservation Union (IUCN) (2001) IUCN Red List Categories: Version 3.1. IUCN Species Survival Commission. IUCN, Gland, Switzerland. http://www.iucnredlist.org/static/categories_criteria_3_1. Cited 2005-2007 